\title{
MEASURING AND TESTING THE PARAMETERS OF A BATTERY PACK DESIGNED FOR POWERING UNMANNED AIRCRAFT SYSTEMS AT VARIOUS TEMPERATURES
}

\author{
Anna M. Mazur*, Tomasz KorniluK*, Roman DomańSKi** \\ * Remote Sensing Division, Center of Space Technologies, Institute of Aviation, Al. Krakowska 110/114, \\ 02-256 Warszawa \\ anna.mazur@ilot.edu.pl,tomasz.korniluk@ilot.edu.pl \\ ** Chairman of Scientific Council, Institute of Aviation, Al. Krakowska 110/114, 02-256 Warszawa \\ roman.domanski@ilot.edu.pl
}

\begin{abstract}
This paper describes results of tests dedicated to studying - in simulated environmental conditions - operation of a battery pack designed for powering unmanned aircraft systems. In particular, the tests concerned determining the electrical parameters of battery packs, with and without radiators, during their operation in changing environmental conditions and resistance to large temperature fluctuations. Amicell, a high density lithium polymer battery manufactured by the Israeli Amit Industries ltd., was selected for testing. The test results present characteristics of the batteries tested in different temperatures and allow for designing and trying out proper battery protections against environmental conditions, with the intention to attain continuous and correct operation. The tests have been carried out in the accredited Environmental Test Laboratory which is part of the Department of Avionics of the Institute of Aviation in Poland.

Keywords: lithium polymer batteries, environmental test laboratory, UAS, Unmanned Aircraft Systems.
\end{abstract}

\section{INTRODUCTION}

The goal of the present study is to determine the electrical parameters of battery packs, with and without radiators, during their operation in changing environmental conditions and obtain voltage and current characteristics vs. time, within the temperature range from $-30^{\circ} \mathrm{C}$ to $+40^{\circ} \mathrm{C}$. The test results present the electrical parameters of the batteries tested in different temperatures. Voltage, current, temperature, and time were recorded during the tests. The following battery 
characteristics were presented: changes of capacity, voltage, and current in the time function, depending on the environment temperature [1 - 6].

The object of testing was verified in respect to parameter functionality and stability in the environmental conditions corresponding to those in which drones operate. The main measurements concerned voltage and current, as well as temperature between particular cells in the battery pack, in accordance with the requirements designed for the batteries meant for powering the drone's electrical motor. The purpose of the test under discussion was to establish the battery's resistance to high temperatures which can occur during the waiting period before take-off from a runway and to low temperatures which can occur at the drone's flight ceiling [7 - 14].

The test results will be used for the verification of calculations and validation of the mathematical models relating to the design of a battery package dedicated to drone powering, as well as heat exchange analysis. The test results will also become the basis for the development of adequate cooling/ heating systems for battery packs, as required in the changing environmental conditions [15 - 17].

The completed tests relied on validated research methods and current substantive testing supervision provided by the members of the Environmental Test Laboratory.

\section{TESTING METHODS}

\subsection{Technical Data of Batteries}

The lithium polymer battery, model ABLP5274JOHG, manufactured by the Israeli Amit Industries Ltd. [18], was selected for testing. The battery is characterized by several features which distinguish it from many other lithium polymer systems available on the market, including e.g. high energy density of about $250 \mathrm{Wh} / \mathrm{kg}$. Fig. 1 presents the dimensions of the Amit single cell battery, and Table 1 presents the reported nominal technical characteristics.

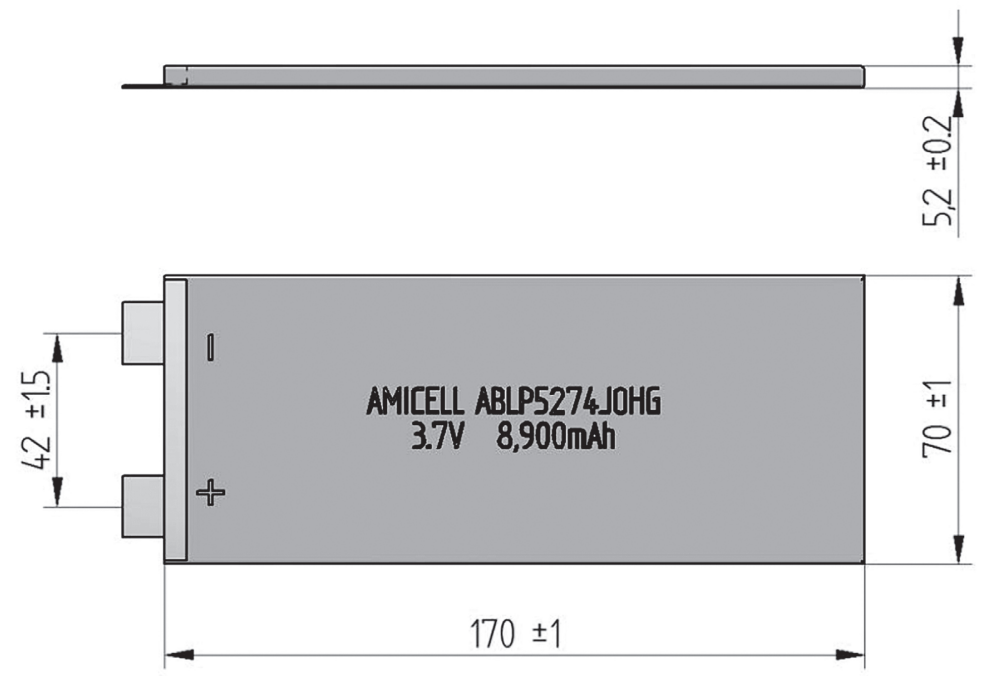

Fig. 1. Battery dimensions [18] 
Tab. 1. Technical specification of the selected battery [18]

\begin{tabular}{|c|c|c|c|c|}
\hline No. & Battery model & \multicolumn{3}{|c|}{ Lithium Polymer Battery/Amit Industries Ltd. } \\
\hline 1 & Catalogue number & \multicolumn{3}{|c|}{ ABLP5274JOHG } \\
\hline \multirow{2}{*}{2} & \multirow{2}{*}{ Dimensions } & Length & Width & Thickness \\
\hline & & $170+/-1 \mathrm{~mm}$ & $70+/-1 \mathrm{~mm}$ & $5.2+/-0.2 \mathrm{~mm}$ \\
\hline 3 & Internal resistance & $>8 \mathrm{~m} \Omega$ & & \\
\hline \multirow{2}{*}{4} & \multirow{2}{*}{ Voltage } & Min. & Nominal & Max. \\
\hline & & $3 \mathrm{~V}$ & $3.7 \mathrm{~V}$ & $4.2 \mathrm{~V}$ \\
\hline \multirow{2}{*}{5} & \multirow{2}{*}{ Capacity } & Min. & Typical & Max. \\
\hline & & 8.6Ah & 8.9Ah & 9Ah \\
\hline \multirow{2}{*}{6} & \multirow{2}{*}{ Weight } & Min. & & \\
\hline & & $138+/-15 \mathrm{gr}$ & & $147 \mathrm{gr}$ \\
\hline 7 & Charging method & $\mathrm{CC}-\mathrm{CV}$ & & \\
\hline 8 & Max. discharge current in ambient temperature & \multicolumn{3}{|c|}{$17.8 \mathrm{~A}(\sim 2 \mathrm{C})$} \\
\hline 9 & Charging current & \multicolumn{3}{|c|}{$2 \mathrm{~A}(\sim 0.2 \mathrm{C})$} \\
\hline 10 & Max. charging voltage & \multicolumn{3}{|c|}{$4.2+/-0.03 \mathrm{~V}$} \\
\hline \multirow{2}{*}{11} & \multirow{2}{*}{ Temperature } & Charge & Discharge & Storage \\
\hline & & $0^{\circ} \mathrm{C}$ to $+40^{\circ} \mathrm{C}$ & $-10^{\circ} \mathrm{C}$ to $+60^{\circ} \mathrm{C}$ & $-20^{\circ} \mathrm{C}$ to $+60^{\circ} \mathrm{C}$ \\
\hline
\end{tabular}

The first battery pack was composed of nine lithium polymer cells connected in series. In addition, thermally conductive tapes were attached to both sides of each cell. The battery pack was coated with Airex thermal insulation foam [19]. The first tested pack did not have any radiators. Figure 2 presents view of the battery pack structure covered by Airex T92 insulation foam (in the back), thus operating near-adiabatically.

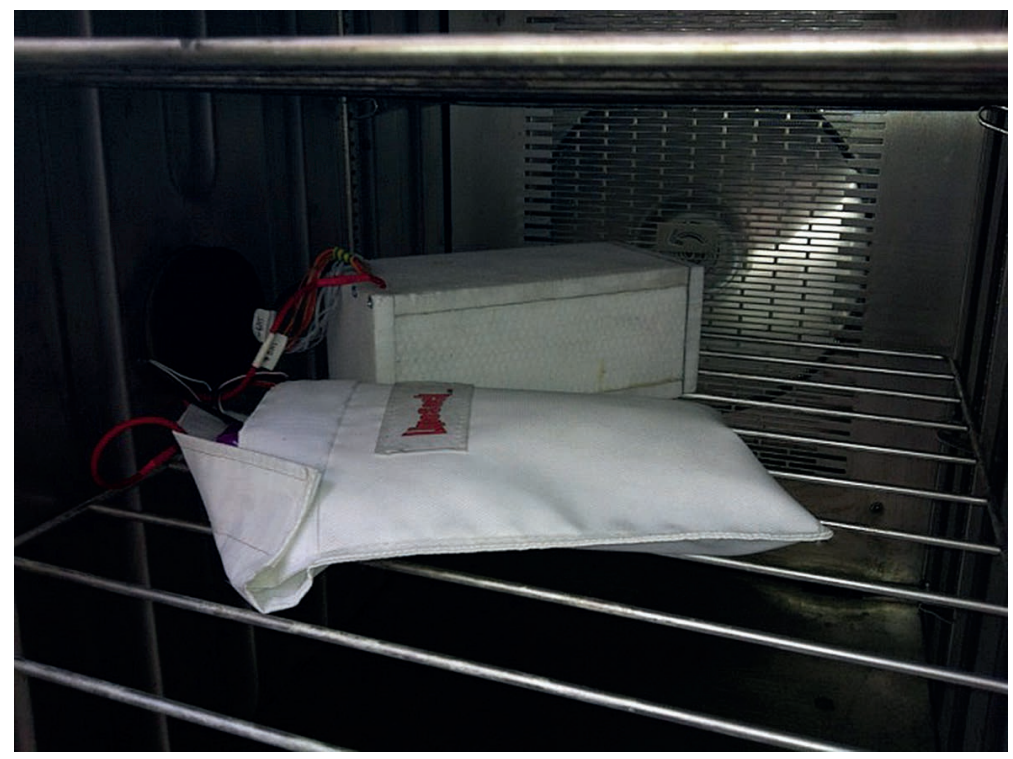

Fig. 2. Battery pack, without a radiator [Mazur, 2014] 
The second battery pack was also composed of 9 Amit lithium polymer cells. Thermally conductive tapes were attached to both sides of each cell. In addition, the battery pack was fitted with aluminium plates between each cell to function as radiators, and this battery pack was simulated near-isothermal operation.

\subsection{Test Description}

The tests conducted in an environmental chamber (Excal 7728-HE, model 8242) to control ambient temperature by increasing or decreasing the temperature every $10 \mathrm{~K}$, within the studied temperature range of $-30^{\circ} \mathrm{C}$ to $+40^{\circ} \mathrm{C}$. Each temperature change of the environmental chamber was followed by a period of time to allow the battery pack temperature to reach the controlled temperature $(30 \div 60$ minutes). Next, parameters were measured by one full charge/discharge cycle with direct current. This was done at each temperature.

\subsection{Test Bench}

The tests were carried out in the accredited Environmental Test Laboratory which is part of the Department of Avionics of the Institute of Aviation in Poland. In addition, a battery charge/discharge system designed in the Institute of Aviation was used to measure voltage under controlled current operation with computer data acquisition. To prevent a sudden battery temperature increase that would pose the hazard of damage, automatic interruption of the power supply was installed. Such a thermal protection for battery charge/discharge was assured by eight temperature sensors.

The test bench was prepared for obtaining electrical characteristics in various environmental conditions. The test bench was designed in a way allowing for electrical measurements of the battery pack and resistance to increased temperature, decreased temperature, cyclic temperature changes, sudden temperature drops, and thermal shocks in the environmental chamber. The test bench was equipped with a battery charge/discharge system composed of the following modules:

- battery charge/discharge controller,

- monitoring system to measure voltage and temperature at particular batteries, with the temperature reading accuracy of $1 \mathrm{~K}$,

- eight temperature sensors for thermal tests and thermal protections for battery charge/discharge,

- power supply controlled by the charge controller. The power supply operated as a controlled source required for battery charging,

- load for battery discharge,

- battery pack,

- thermal coating made of Airex thermal insulation foam,

- multimeter,

- PC computer collecting logs from the controller. It also turns the battery charge/discharge on and off, using proper current,

- Excal 7728-HE, model 8242, environmental chamber.

Figure 3 shows view of the test bench. 


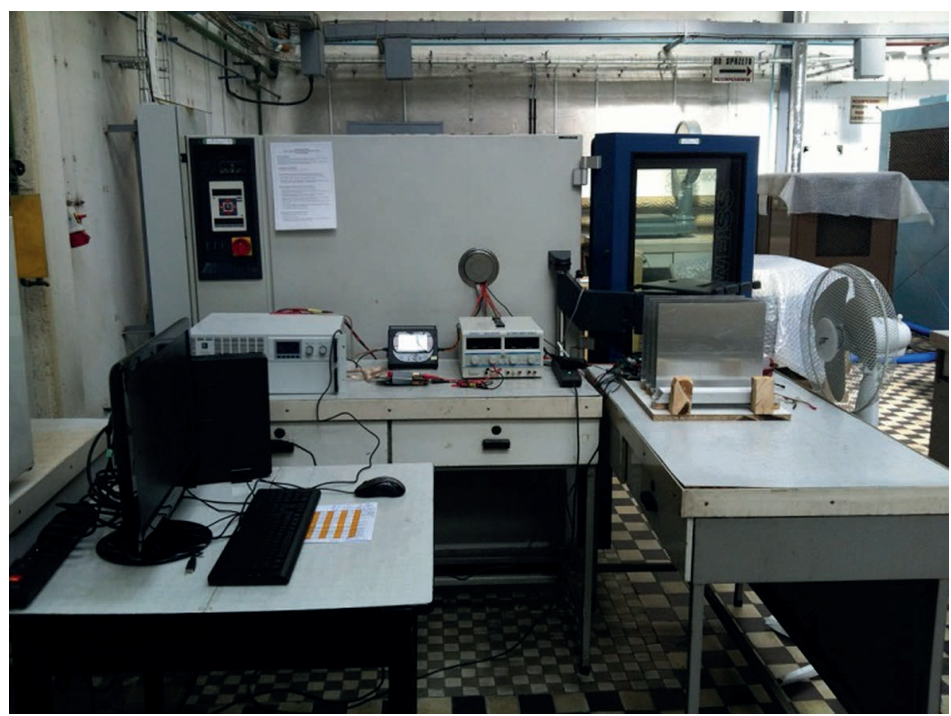

Fig. 3. Test bench: environmental chamber [Mazur, 2014]

\subsection{Testing description}

Battery pack tests were conducted in two stages:

Stage I: at ambient temperature of $20^{\circ} \mathrm{C}$ and various temperatures (near adiabatic),

Stage II: under controlled (near-isothermal) conditions in order to determine the effect of temperature on performance.

The tests were conducted in an environmental chamber, in the ambient temperature set at $20^{\circ} \mathrm{C}$. Three charge/discharge cycles were conducted in that temperature for three different discharge currents $(0.5 \mathrm{C}$; $1 \mathrm{C}$; and $2 \mathrm{C})$.

Stage I: Battery Pack One, without a Radiator in the Environmental Chamber

The tests were conducted in various environmental conditions for various discharge currents, $0.5 \mathrm{C}, 1 \mathrm{C}$, and $2 \mathrm{C}$.

No test was made at $+40^{\circ} \mathrm{C}$, because overheating occurred at $+30^{\circ} \mathrm{C}$ during the discharge process. The battery pack was also discharged with $4.5 \mathrm{~A}(0.5 \mathrm{C})$ and $9 \mathrm{~A}(1 \mathrm{C})$ currents in the low temperature of $-20^{\circ} \mathrm{C}$.

The conditions of Stage I are presented in table 2.

Stage II: Battery Pack Two, near isothermal condition using a Radiator in the Environmental Chamber

The battery pack was composed of the same batteries, with thermally conductive pads and additional aluminium plates serving as radiators removing heat from the battery pack. The tests were conducted in various environmental conditions, in the temperatures of $+30^{\circ} \mathrm{C}$ and $+40^{\circ} \mathrm{C}$, for various discharge currents: $0.5 \mathrm{C}, 1 \mathrm{C}$, and $2 \mathrm{C}$.

The conditions of Stage II are presented in table 3. 
Measuring and Testing the Parameters of a Battery Pack Designed...

Table 2. Thermal test design for Battery Pack One, without a radiator [Mazur, 2014]

\begin{tabular}{|c|c|c|c|c|c|c|c|c|}
\hline \multicolumn{9}{|c|}{ Battery pack testing, with thermal insulation } \\
\hline \multirow[b]{2}{*}{ No. } & \multirow[b]{2}{*}{$\begin{array}{c}\text { Temp. } \\
{\left[{ }^{\circ} \mathrm{C}\right]}\end{array}$} & \multirow[b]{2}{*}{$\begin{array}{l}\text { Pressure } \\
{[\mathrm{hPa}]}\end{array}$} & \multirow[b]{2}{*}{$\begin{array}{c}\text { Charge } \\
\text { current } \\
\text { [A] }\end{array}$} & \multirow[b]{2}{*}{$\begin{array}{l}\text { Discharge } \\
\text { current } \\
{[\mathrm{A}]}\end{array}$} & \multirow[b]{2}{*}{$\begin{array}{c}\text { Temperature } \\
\text { stabilization time } \\
{[\mathrm{h}]}\end{array}$} & \multicolumn{3}{|c|}{ Time [h] } \\
\hline & & & & & & $\begin{array}{c}\text { Estimated } \\
\text { charging } \\
\text { time } \\
{[\mathrm{h}]}\end{array}$ & $\begin{array}{c}\text { Estimated } \\
\text { discharging } \\
\text { time } \\
{[\mathrm{h}]}\end{array}$ & $\begin{array}{l}\text { Estimated total } \\
\text { time } \\
{[\mathrm{h}]}\end{array}$ \\
\hline 1 & 20 & 1013 & 3 & 4.5 & 1 & 4 & 2 & 7 \\
\hline 2 & 20 & 1013 & 3 & 9 & 1 & 4 & 1 & 6 \\
\hline 3 & 20 & 1013 & 3 & 18 & 1 & 4 & 0.5 & 5.5 \\
\hline 4 & 30 & 1013 & 3 & 4.5 & 1 & 4 & 2 & 7 \\
\hline 5 & 30 & 1013 & 3 & 9 & 1 & 4 & 1 & 6 \\
\hline 6 & 30 & 1013 & 3 & 18 & 1 & 4 & 0.5 & 5.5 \\
\hline 7 & 40 & 1013 & 3 & 4.5 & 1 & 4 & 2 & 7 \\
\hline 8 & 40 & 1013 & 3 & 9 & 1 & 4 & 1 & 6 \\
\hline 9 & 40 & 1013 & 3 & 18 & 1 & 4 & 0.5 & 5.5 \\
\hline 10 & 10 & 1013 & 3 & 4.5 & 1 & 4 & 2 & 7 \\
\hline 11 & 10 & 1013 & 3 & 9 & 1 & 4 & 1 & 6 \\
\hline 12 & 10 & 1013 & 3 & 18 & 1 & 4 & 0.5 & 5.5 \\
\hline 13 & 0 & 1013 & 3 & 4.5 & 1 & 4 & 2 & 7 \\
\hline 14 & 0 & 1013 & 3 & 9 & 1 & 4 & 1 & 6 \\
\hline 15 & 0 & 1013 & 3 & 18 & 1 & 4 & 0.5 & 5.5 \\
\hline 16 & -10 & 1013 & 3 & 4.5 & 1 & 4 & 2 & 7 \\
\hline 17 & -10 & 1013 & 3 & 9 & 1 & 4 & 1 & 6 \\
\hline 18 & -10 & 1013 & 3 & 18 & 1 & 4 & 0.5 & 5.5 \\
\hline 19 & -20 & 1013 & 3 & 4.5 & 1 & 4 & 2 & 7 \\
\hline 20 & -20 & 1013 & 3 & 9 & 1 & 4 & 1 & 6 \\
\hline 21 & -20 & 1013 & 3 & 18 & 1 & 4 & 0.5 & 5.5 \\
\hline 22 & -30 & 1013 & 3 & 4.5 & 1 & 4 & 2 & 7 \\
\hline 23 & -30 & 1013 & 3 & 9 & 1 & 4 & 1 & 6 \\
\hline 24 & -30 & 1013 & 3 & 18 & 1 & 4 & 0.5 & 5.5 \\
\hline
\end{tabular}

Tab. 3. Thermal test design for Battery Pack Two, with a radiator [Mazur, 2014]

\begin{tabular}{|c|c|c|c|c|c|c|c|c|}
\hline \multicolumn{9}{|c|}{ Battery pack testing, with thermal insulation } \\
\hline \multirow[b]{2}{*}{ No. } & \multirow[b]{2}{*}{$\begin{array}{c}\text { Temperature } \\
\text { [C] }\end{array}$} & \multirow[b]{2}{*}{$\begin{array}{l}\text { Pressure } \\
{[\mathrm{hPa}]}\end{array}$} & \multirow[b]{2}{*}{$\begin{array}{l}\text { Charge } \\
\text { current } \\
\text { [A] }\end{array}$} & \multirow[b]{2}{*}{$\begin{array}{c}\text { Discharge } \\
\text { current } \\
{[\mathrm{A}]}\end{array}$} & \multirow[b]{2}{*}{$\begin{array}{c}\text { Temperature } \\
\text { stabilization time } \\
{[\mathrm{h}]}\end{array}$} & \multicolumn{3}{|c|}{ Time $[\mathrm{h}]$} \\
\hline & & & & & & $\begin{array}{l}\text { Estimated } \\
\text { charge time } \\
{[\mathrm{h}]}\end{array}$ & $\begin{array}{c}\text { Estimated } \\
\text { discharge } \\
\text { time } \\
{[\mathrm{h}]} \\
\end{array}$ & $\begin{array}{l}\text { Estimated total } \\
\text { time } \\
{[\mathrm{h}]}\end{array}$ \\
\hline 1 & 30 & 1013 & 3 & 4.5 & 1 & 4 & 2 & 7 \\
\hline 2 & 30 & 1013 & 3 & 9 & 1 & 4 & 1 & 6 \\
\hline 3 & 30 & 1013 & 3 & 18 & 1 & 4 & 0.5 & 5.5 \\
\hline 4 & 40 & 1013 & 3 & 4.5 & 1 & 4 & 2 & 7 \\
\hline 5 & 40 & 1013 & 3 & 9 & 1 & 4 & 1 & 6 \\
\hline 6 & 40 & 1013 & 3 & 18 & 1 & 4 & 0.5 & 5.5 \\
\hline & & & & & & & tal time $[\mathrm{h}]$ & 37 \\
\hline
\end{tabular}


The battery pack after being charged was placed in an environmental chamber, with the required temperature, for 1 hour in order for the temperature to stabilize. Next, the battery was discharged in the same temperature with the set current (that was a single full test cycle). Data recording was carried out with the use of a computer application LogView. Consequently, the influence of the surrounding temperature on the battery data was tested and it could be compared to the results of the tests conducted in ambient temperature.

\section{RESULTS}

Stage I: Battery Pack One, without a Radiator in the Environmental Chamber

Measurements of Battery Pack One, without a radiator, taken at $+20^{\circ} \mathrm{C}$.

Fig. 4. presents a voltage drop during the battery pack discharge in the ambient temperature of $+20^{\circ} \mathrm{C}$, using the currents of $4.5 \mathrm{~A}, 9 \mathrm{~A}$, and $18 \mathrm{~A}$.

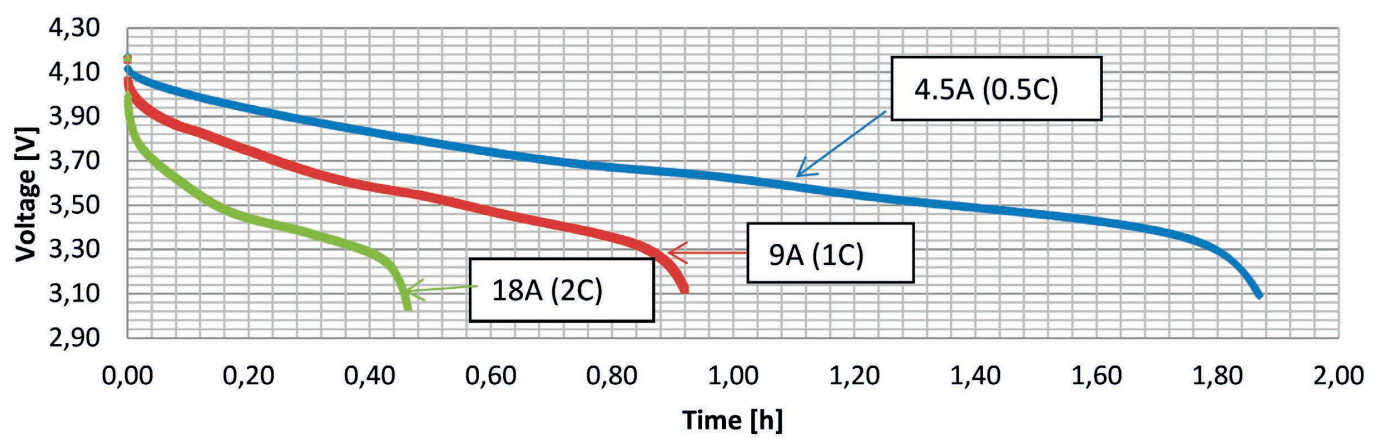

Fig. 4. Comparison of discharge results, with various currents and at $20^{\circ} \mathrm{C}$ (without a radiator) [Mazur, 2014]

A comparison of discharge results, with various currents and in the same temperature.

Fig. 5 presents the voltage drop during discharge in the temperature of $-20^{\circ} \mathrm{C}$ and at 4.5 and $9 \mathrm{~A}$.

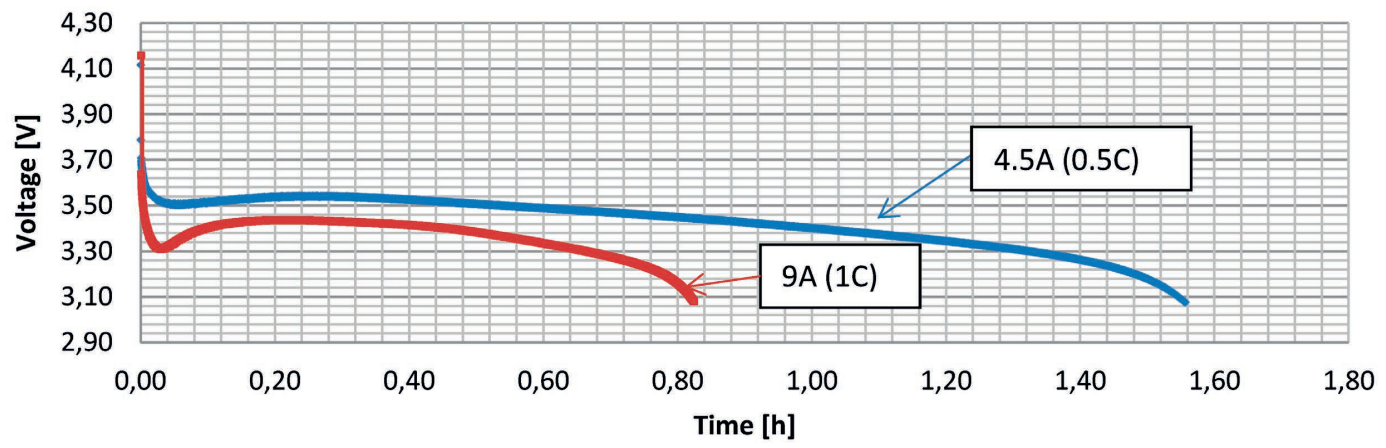

Fig. 5. Comparison of discharge results, with various currents and at $-20^{\circ} \mathrm{C}$ [Mazur, 2014] 


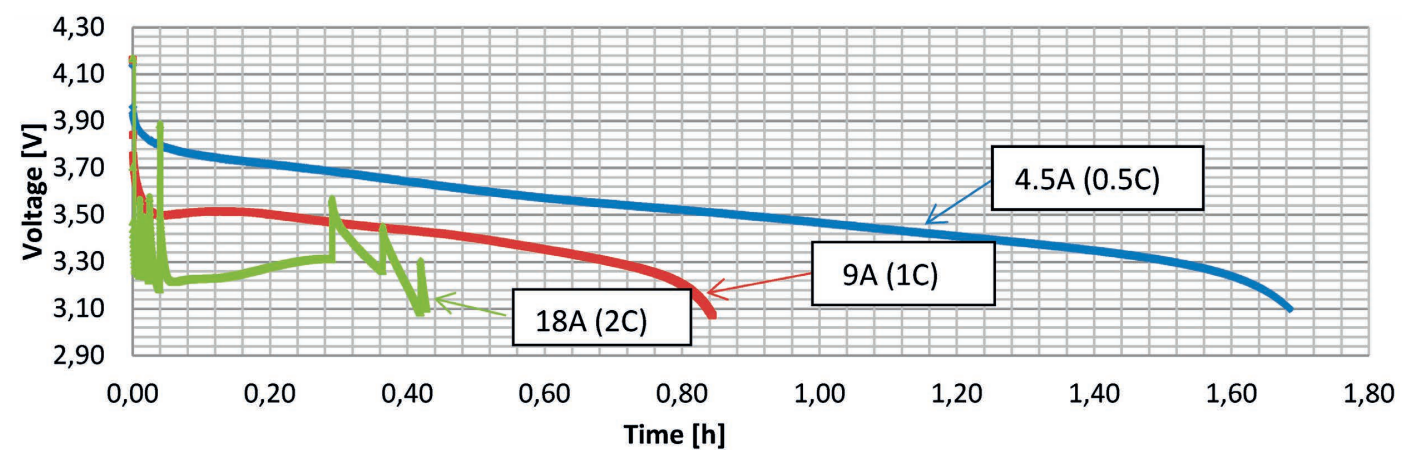

Fig. 6. Comparison of discharge results, with various currents and at $-10^{\circ} \mathrm{C}$ [Mazur, 2014]

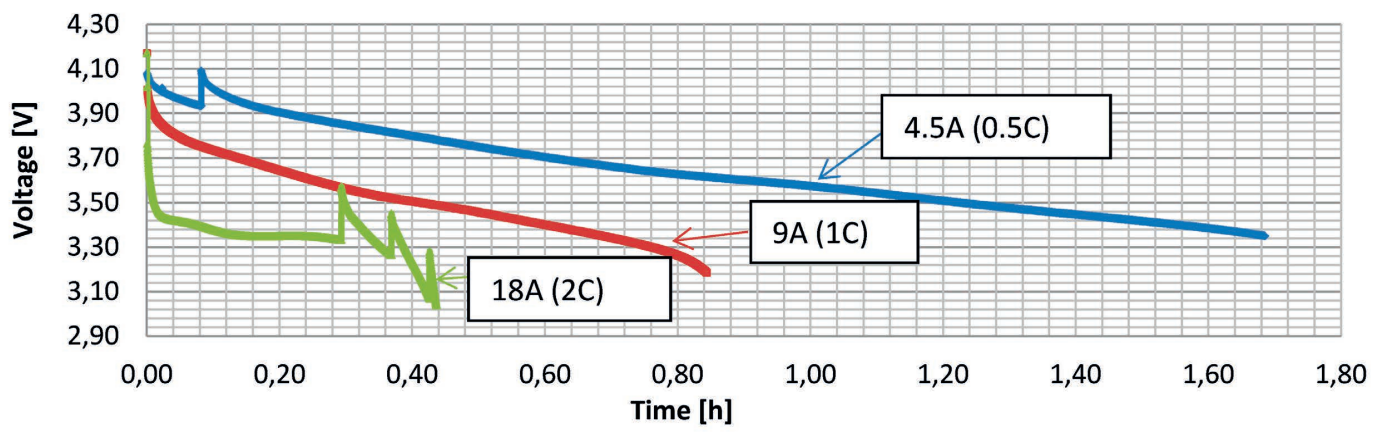

Fig. 7. Comparison of discharge results, with various currents and at $0^{\circ} \mathrm{C}$ [Mazur, 2014]

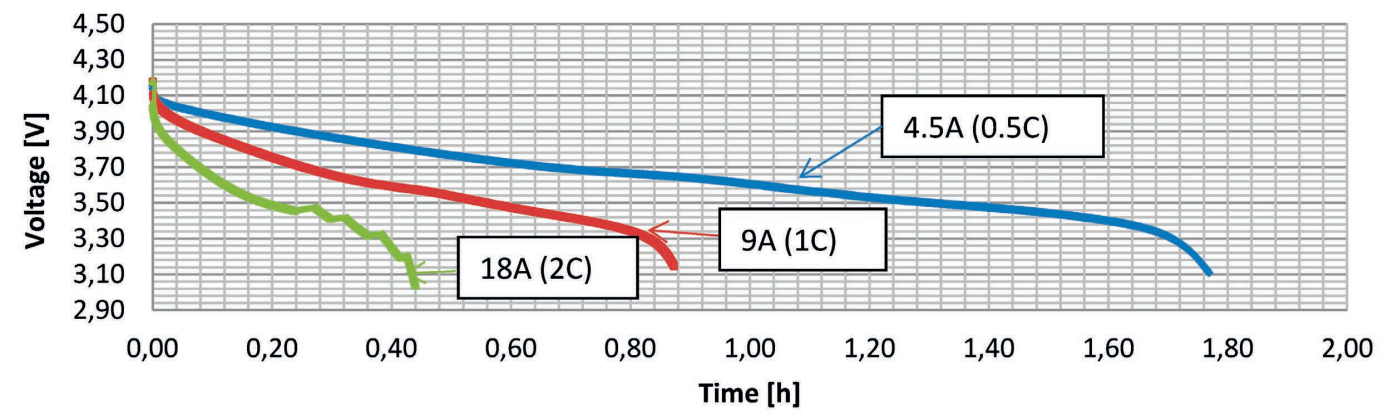

Fig. 8. Comparison of discharge results, with various currents and at $30^{\circ} \mathrm{C}$ [Mazur, 2014]

Fig. 6 presents the voltage drop during discharge in the temperature of $-10^{\circ} \mathrm{C}$ and at $4.5,9$, and $18 \mathrm{~A}$. Fig. 7 presents the voltage drop during discharge in the temperature of $0^{\circ} \mathrm{C}$ and at $4.5,9$, and $18 \mathrm{~A}$. Fig. 8 presents the voltage drop during discharge in the temperature of $30^{\circ} \mathrm{C}$ and at $4.5,9$, and $18 \mathrm{~A}$. Fig. 9 presents the voltage drop during discharge at different temperatures at $4.5 \mathrm{~A}$.

Fig. 10 presents the voltage drop during discharge at various currents $4.5,9 \mathrm{~A}$ and $18 \mathrm{~A}$. 


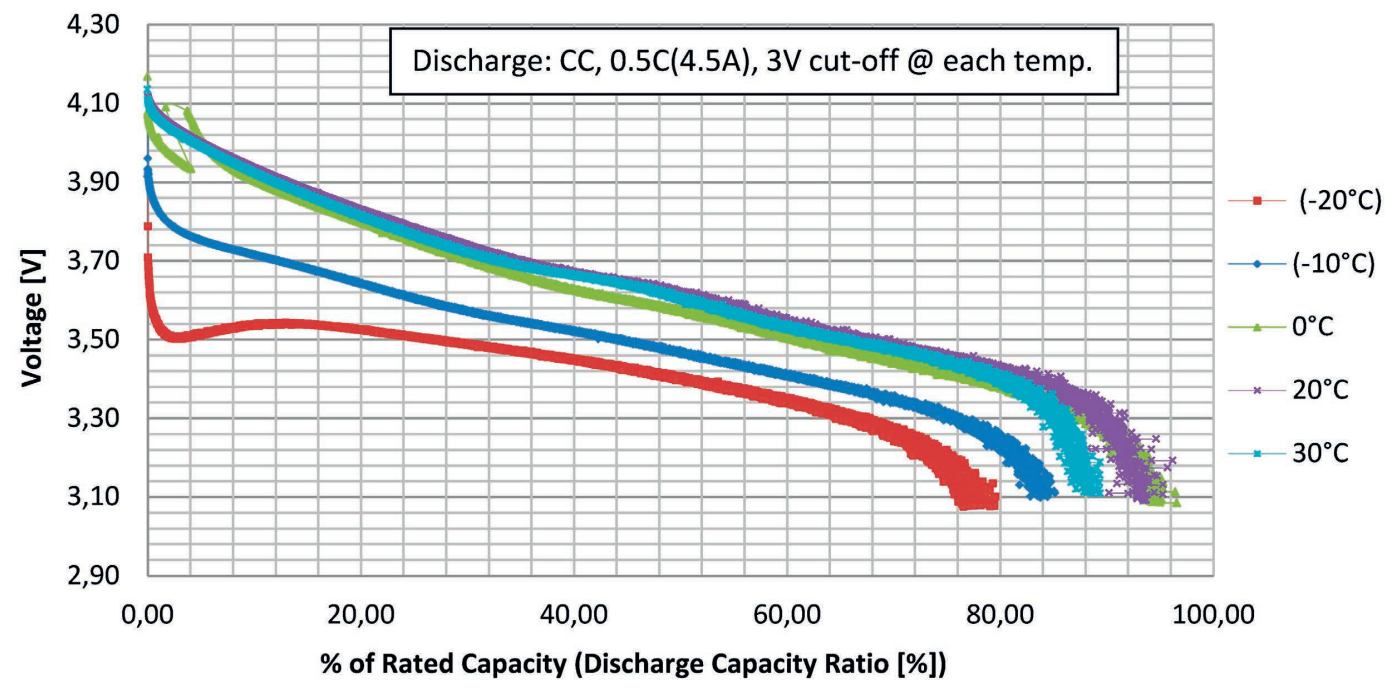

Fig. 9. Comparison of discharge results with current 0.5C at different temperatures [Mazur, 2014]

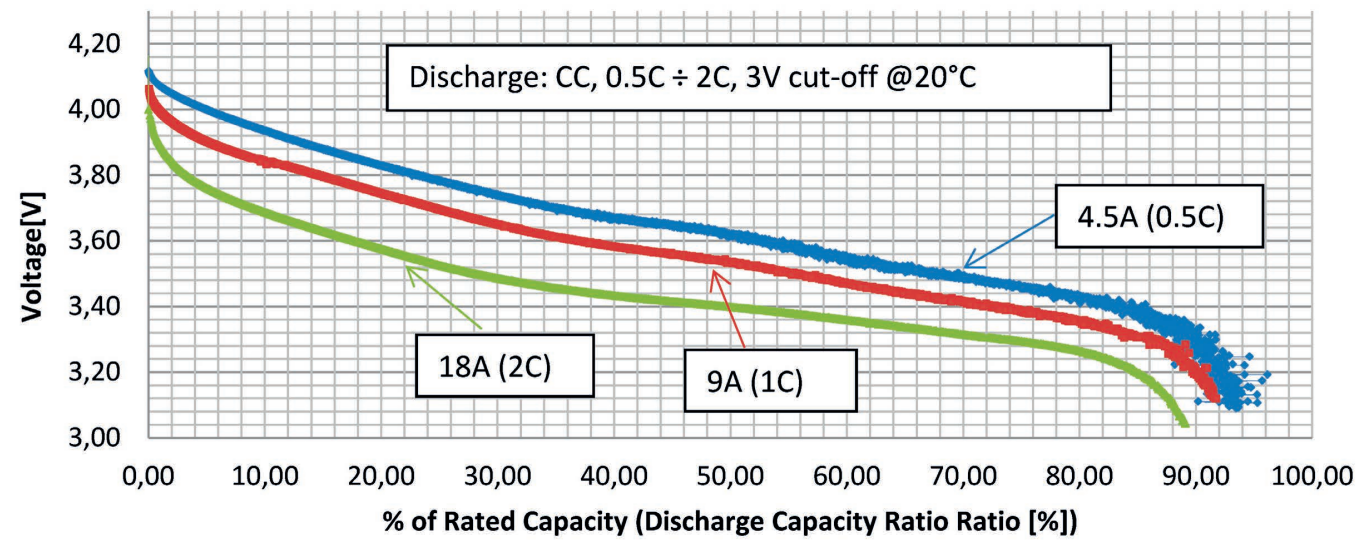

Fig. 10. Comparison of discharge results with current 0.5C at different temperatures [Mazur, 2014]

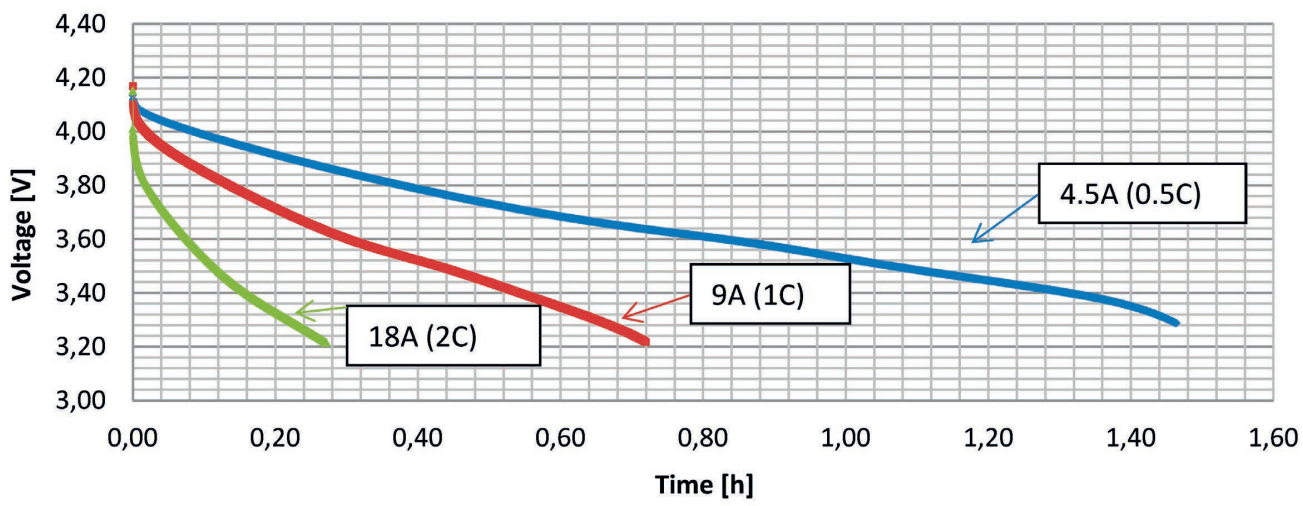

Fig. 11. Comparison of the discharge results, with various currents and at $30^{\circ} \mathrm{C}$ [Mazur, 2014] 
Stage II: battery pack two, near isothermal condition using a radiator in the environmental chamber

The battery pack with a radiator was tested at two temperatures: $30^{\circ} \mathrm{C}$ and $40^{\circ} \mathrm{C}$. The graphs below present the comparisons of discharge data, with various currents and at the same temperature.

Fig. 11 presents the voltage drop during discharge in the temperature of $30^{\circ} \mathrm{C}$ and at $4.5,9$, and $18 \mathrm{~A}$. Fig. 12 presents the voltage drop during discharge at the temperature of $40^{\circ} \mathrm{C}$ ad at $4.5,9$, and $18 \mathrm{~A}$. Fig. 13 presents the voltage drop during discharge at the temperature of $30^{\circ} \mathrm{C}$ ad at $4.5,9$, and $18 \mathrm{~A}$. Fig. 14 presents the voltage drop during discharge at the temperature of $40^{\circ} \mathrm{C}$ and at $4.5,9$, and $18 \mathrm{~A}$. Fig. 15 presents the voltage drop during discharge at the temperature of $40^{\circ} \mathrm{C}$ and at $4.5 \mathrm{~A}$.

A comparison of test results of the batteries with and without radiators

Discharge with 4.5 A (0.5C)

Fig. 16 presents a comparison of the capacity and temperature changes, with and without a radiator, at $30^{\circ} \mathrm{C}$ and with $4.5 \mathrm{~A}$.

Discharge with 9 A (1C)

Fig. 17 presents a comparison of the capacity and temperature changes, with and without a radiator, at $30^{\circ} \mathrm{C}$ and with $9 \mathrm{~A}$.

\section{Discharge with 18 A (2C)}

Fig. 18 presents a comparison of the capacity and temperature changes, with and without a radiator, at $30^{\circ} \mathrm{C}$ and with $18 \mathrm{~A}$.

The collection of all the results presented in one graph (Fig. 21.).

Fig. 19 presents a comparison of the capacity and temperature changes, with and without a radiator, at $30^{\circ} \mathrm{C}$ and with the currents of $4.5,9$, and $18 \mathrm{~A}$, respectively.

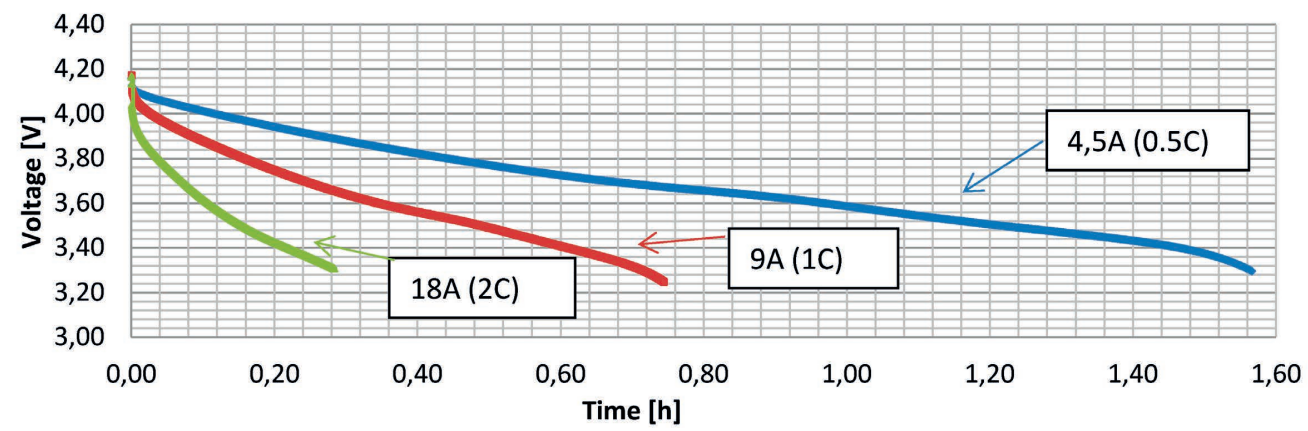

Fig. 12. Comparison of the discharge results, with various currents and at $40^{\circ} \mathrm{C}$ [Mazur, 2014] 


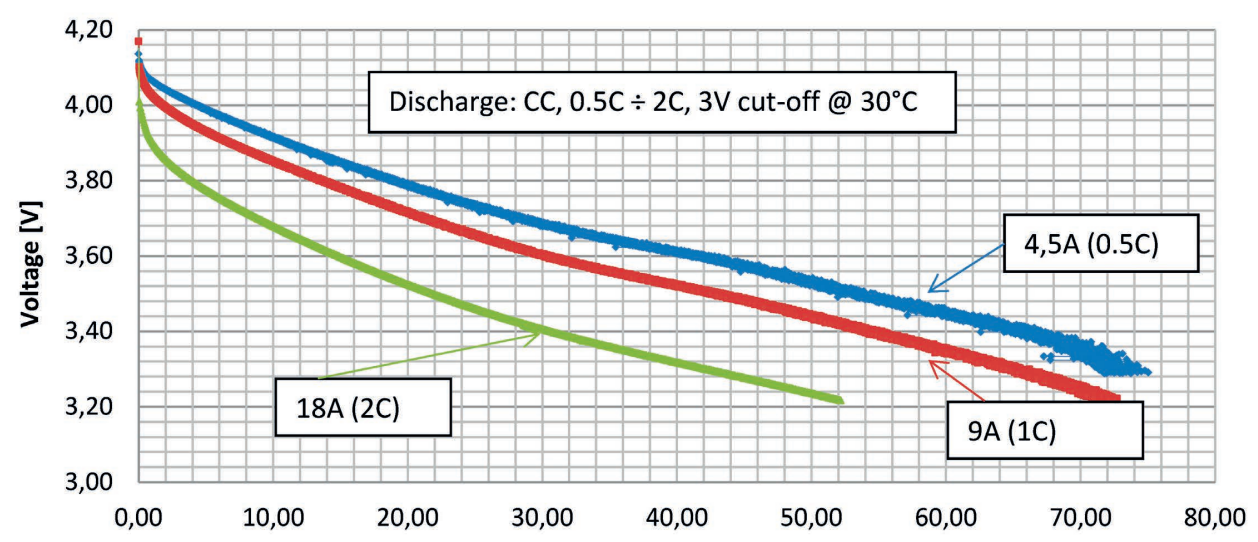

$\%$ of Rated Capacity (Discharge Capacity Ratio [\%])

Fig. 13. Comparison of the discharge results, with various currents and at $30^{\circ} \mathrm{C}$ [Mazur, 2014]

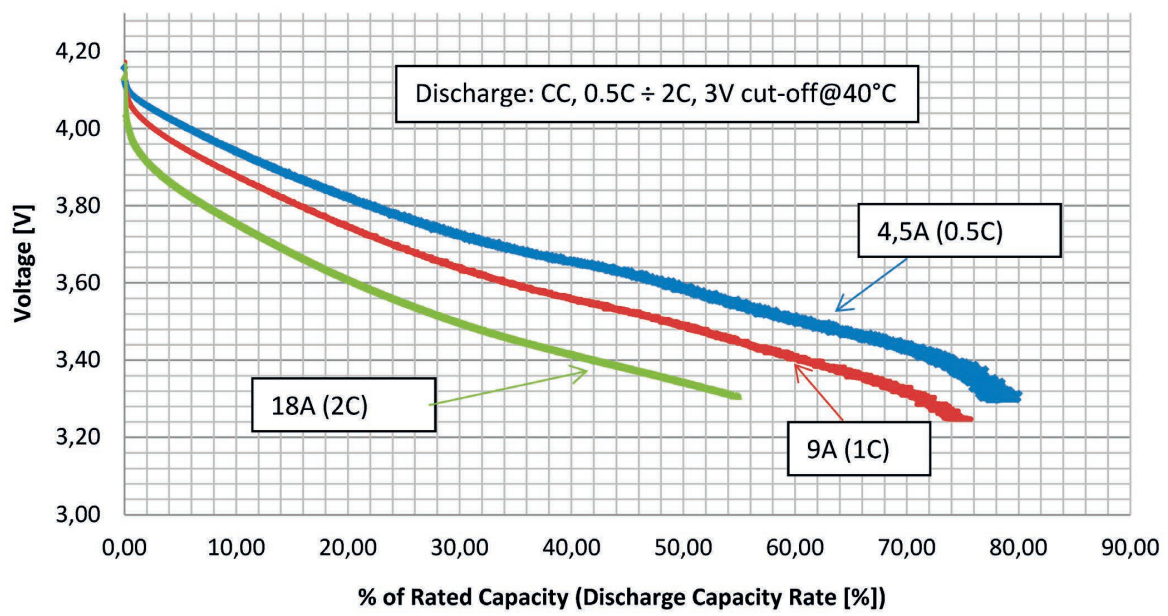

Fig. 14. Comparison of the discharge results, with various currents and at $40^{\circ} \mathrm{C}$ [Mazur, 2014]

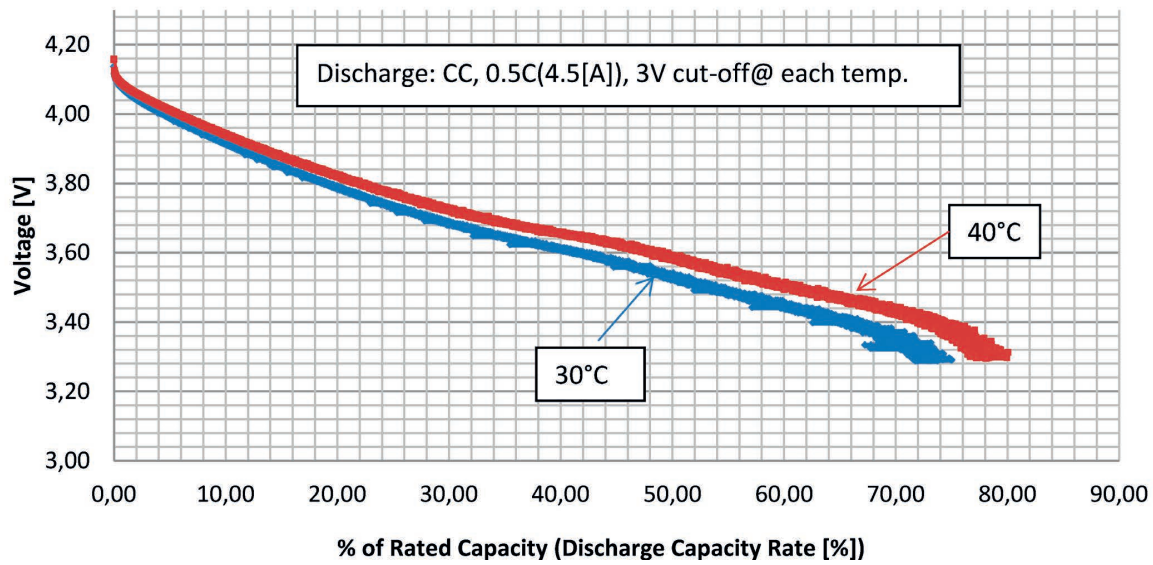

Fig. 15. Comparison of the discharge results in the temperature of $40^{\circ} \mathrm{C}$ and at $4.5 \mathrm{~A}$ [Mazur, 2014] 


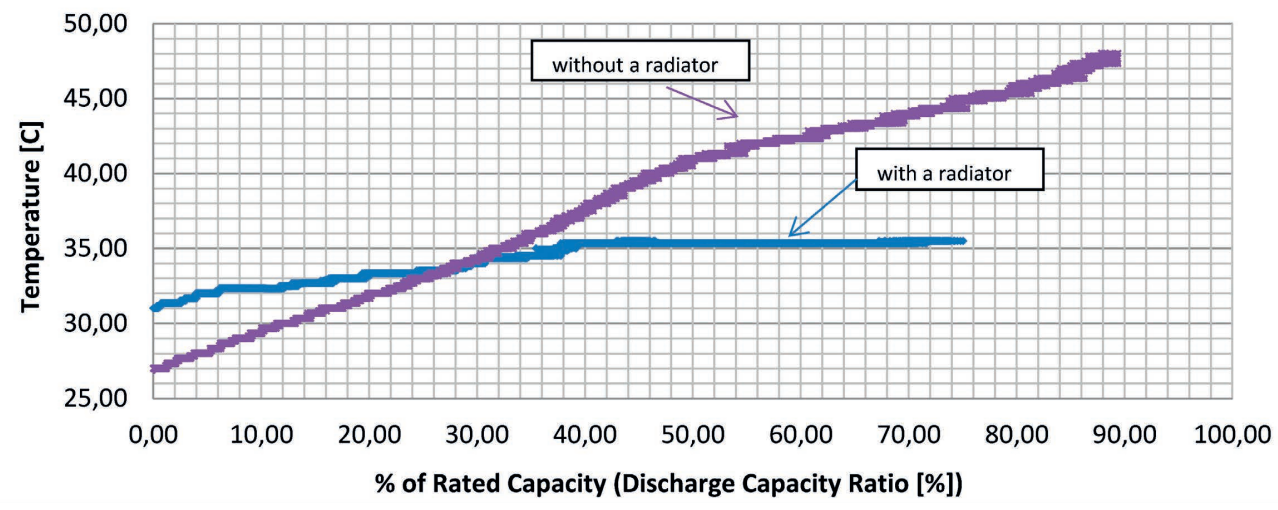

Fig. 16. Comparison of test results, with $4.5 \mathrm{~A}$ and at $30^{\circ} \mathrm{C}$, with and without a radiator [Mazur, 2014]

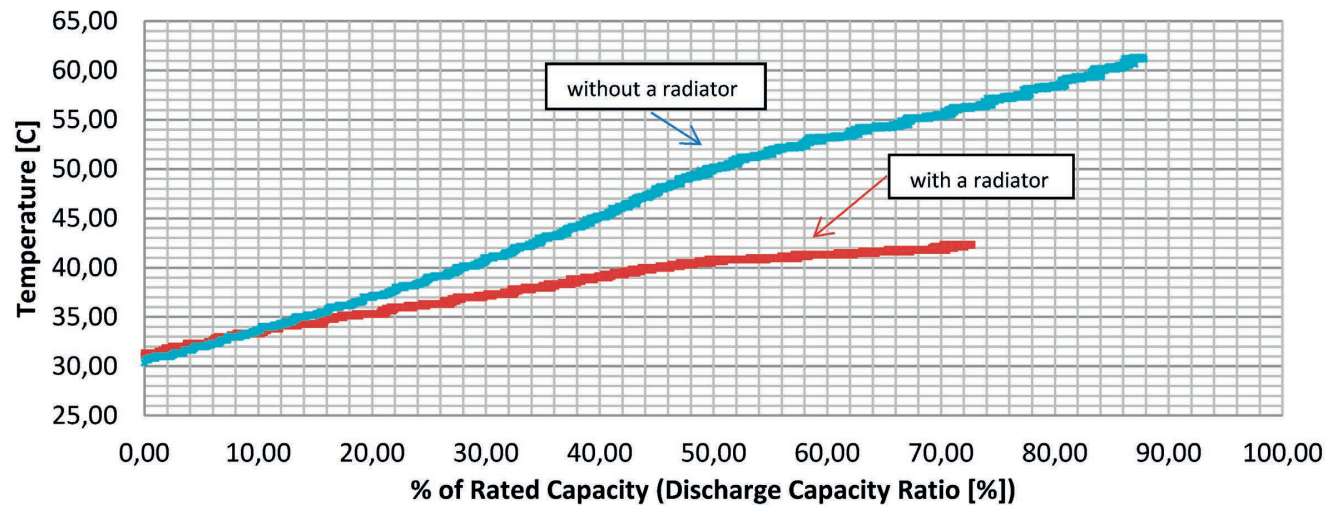

Fig. 17. Comparison of test results, with $9 \mathrm{~A}$ and at $30^{\circ} \mathrm{C}$, with and without a radiator [Mazur, 2014]

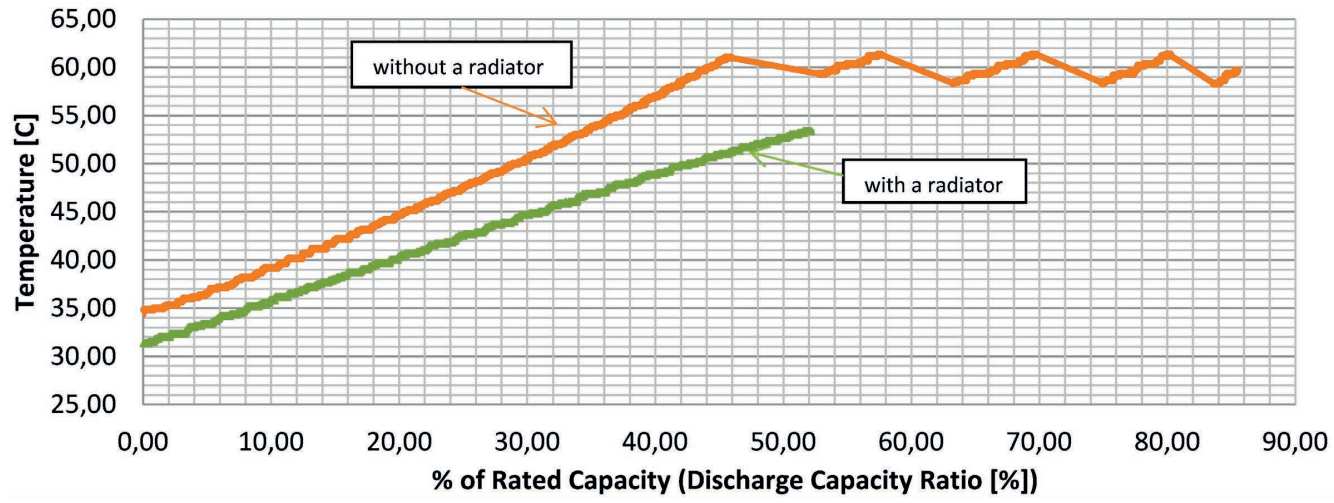

Fig. 18. Comparison of test results, with $18 \mathrm{~A}$ and at $30^{\circ} \mathrm{C}$, with and without a radiator [Mazur, 2014] 


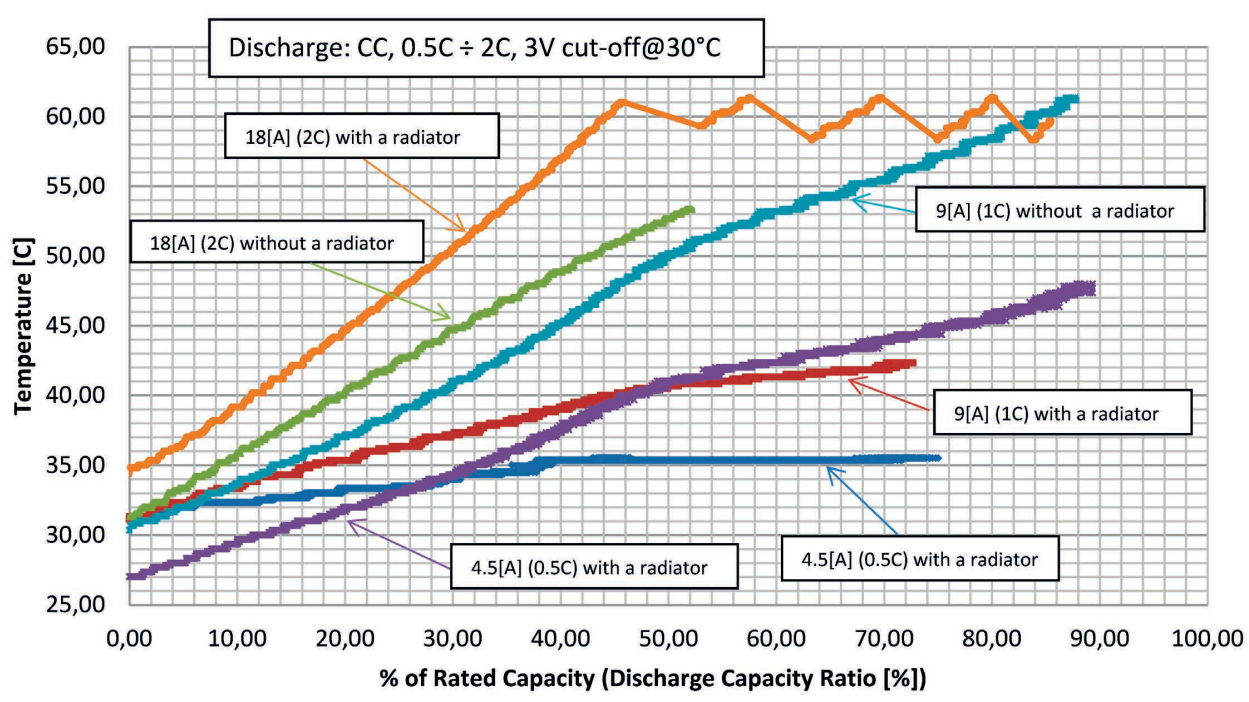

Fig. 19. Comparison of the test results, with various currents at $30^{\circ} \mathrm{C}$, with and without a radiator [Mazur, 2014]

\section{CONCLUSIONS}

The completed tests indicate that the temperature changes between particular batteries in a pack composed of nine cells, ranged from $0^{\circ}$ to $2^{\circ} \mathrm{C}$, depending on the applied current. The uneven temperature distribution should not affect the battery operation.

\section{Stage I: battery pack one, without a radiator in the environmental chamber}

The tests were conducted in an environmental chamber at the temperature set for $20^{\circ} \mathrm{C}$. Three battery charge/discharge cycles were conducted at that temperature using three different discharge currents $(0.5 \mathrm{C} ; 1 \mathrm{C}$; and $2 \mathrm{C})$. The ambient temperature tests indicated that overheating occurred when the battery pack was discharged with $2 \mathrm{C}$. In the case of discharging the pack with $2 \mathrm{C}$, the pack obtained the highest temperature of more than $70^{\circ} \mathrm{C}$, which exceeded the maximum allowed discharge temperature determined in the manufacturer's technical specification $\left(60^{\circ} \mathrm{C}\right)$. When the battery pack was discharged with $1 \mathrm{C}$, the highest temperature reached more than $55^{\circ} \mathrm{C}$, and more than $40^{\circ} \mathrm{C}$ with $0.5 \mathrm{C}$.

The tests were conducted in various environmental conditions, from -20 to $+30^{\circ} \mathrm{C}$ and with various discharge currents: $0.5 \mathrm{C}, 1 \mathrm{C}$, and $2 \mathrm{C}$. No test was conducted at $+40^{\circ} \mathrm{C}$ because the battery pack was overheated during discharge at $+30^{\circ} \mathrm{C}$. At $+30^{\circ} \mathrm{C}$, the battery pack temperature increased to $60^{\circ} \mathrm{C}$ when the pack was discharged with $1 \mathrm{C}$ and $2 \mathrm{C}$. In that temperature, the programmed protection set at $60^{\circ} \mathrm{C}$ did not allow for further temperature increase. When the battery pack was discharged with $0.5 \mathrm{C}$, the maximum pack temperature reached about $48^{\circ} \mathrm{C}$. About $95 \%$ of the pack's capacity was preserved in those conditions. At $0^{\circ} \mathrm{C}$ and with $18 \mathrm{~A}$ discharge current, the pack obtained the maximum allowed temperature of about $60^{\circ} \mathrm{C}$. With $9 \mathrm{~A}$, the pack's temperature reached $50^{\circ} \mathrm{C}$, and with $4.5 \mathrm{~A}$, the temperature reached about $30^{\circ} \mathrm{C}$. When the pack was discharged with either 
$0.5 \mathrm{C}, 1 \mathrm{C}$ or $2 \mathrm{C}$, the capacity was maintained at the level of $85 \%$. At the temperature of $-10^{\circ} \mathrm{C}$ and with the discharge current of $18 \mathrm{~A}$, the battery pack obtained the maximum allowed temperature of about $60^{\circ} \mathrm{C}$. With $9 \mathrm{~A}$, the pack's temperature reached above $50^{\circ} \mathrm{C}$, and with $4.5 \mathrm{~A}$, the temperature reached more than $30^{\circ} \mathrm{C}$. When the pack was discharged with either $0.5 \mathrm{C}, 1 \mathrm{C}$ or $2 \mathrm{C}$, the capacity was preserved at the level of $85 \%$. At low temperature $\left(-20^{\circ} \mathrm{C}\right)$, the battery pack was discharged only with 4.5 and 9A. In that temperature and with the discharge current of 9A, the battery pack reached $50^{\circ} \mathrm{C}$, which allowed for maintaining $85 \%$ capacity. However, with the $4.5 \mathrm{~A}$ discharge current, the pack reached $30^{\circ} \mathrm{C}$ maintaining only $80 \%$ of the pack's capacity.

Depending on temperature and the selected discharge current, the highest capacity was maintained as follows:

- with the discharge current of $4.5 \mathrm{~A}$

- At $20^{\circ} \mathrm{C}$ and $0^{\circ} \mathrm{C}$ : about $100 \%$ capacity

- At $30^{\circ} \mathrm{C}$ : about $95 \%$ capacity

- $\quad$ In the remaining temperatures: about $80 \%$ capacity

- with the discharge current of 9A

- At $20^{\circ} \mathrm{C}$ : about $95 \%$ capacity

- At $30^{\circ} \mathrm{C}$ and $0^{\circ} \mathrm{C}$ : about $90 \%$ capacity

- $\quad$ In the remaining temperatures: about $80 \%$ capacity

- with the discharge current of $18 \mathrm{~A}$

- At $20^{\circ} \mathrm{C}$ : about $90 \%$ capacity

- At $30^{\circ} \mathrm{C}$ and $0^{\circ} \mathrm{C}$ : about $85 \%$ capacity

- In the remaining temperatures: below $80 \%$ capacity

The above considerations suggest that the highest capacity can be maintained when discharging the battery at $20^{\circ} \mathrm{C}, 30^{\circ} \mathrm{C}$, and $0^{\circ} \mathrm{C}$. High performance at $0^{\circ} \mathrm{C}$ may result from the fact that the heat generated during the battery discharge was adequate to ensure proper thermal conditions for particular cells. The tests conducted on single batteries indicated that capacity was much lower at $0^{\circ} \mathrm{C}$.

\section{Stage II: Battery Pack Two, near isothermal condition using a Radiator in the Environmental Chamber}

The tests were conducted in various environmental conditions at $+30^{\circ} \mathrm{C}$ and $+40^{\circ} \mathrm{C}$, with various discharge currents: $0.5 \mathrm{C}, 1 \mathrm{C}$, and $2 \mathrm{C}$. At $30^{\circ} \mathrm{C}$ and with $18 \mathrm{~A}$, the battery pack obtained the maximum allowed temperature of more than $50^{\circ} \mathrm{C}$. With $9 \mathrm{~A}$ and at $40^{\circ} \mathrm{C}$, and with $4.5 \mathrm{~A}$, the pack's temperature reached about $35^{\circ} \mathrm{C}$. When the pack was discharged with $0.5 \mathrm{C}$, capacity was maintained at the level of $80 \%$.

- With $1 \mathrm{C}$ discharge current, capacity was maintained at the level of $75 \%$.

- With $2 \mathrm{C}$ discharge current, capacity was maintained at the level of $50 \%$.

At $40^{\circ} \mathrm{C}$ and the discharge current of $18 \mathrm{~A}$, the package obtained the maximum allowed temperature of about $60^{\circ} \mathrm{C}$. At $9 \mathrm{~A}$, more than $50^{\circ} \mathrm{C}$, and at $4.5 \mathrm{~A}$, more than $45^{\circ} \mathrm{C}$. At the discharge current of $0.5 \mathrm{C}$, capacity was maintained at the level of $80 \%$.

- With $1 \mathrm{C}$ discharge current, capacity was maintained at the level of $75 \%$.

- With $2 \mathrm{C}$ discharge current, capacity was maintained at the level of $50 \%$. 
Depending on temperature and the selected discharge current, the highest capacity was maintained as follows:

- with the discharge current of $4.5 \mathrm{~A}$

- At $40^{\circ} \mathrm{C}$ : about $85 \%$ capacity

- At $30^{\circ} \mathrm{C}$ : about $80 \%$ capacity

- with the discharge current of 9A

- At $40^{\circ} \mathrm{C}$ : about $80 \%$ capacity

- $\quad$ At $30^{\circ} \mathrm{C}$ and $0{ }^{\circ} \mathrm{C}$ : about $75 \%$ capacity

- with the discharge current of $18 \mathrm{~A}$

- At $40^{\circ} \mathrm{C}$ : about $60 \%$ capacity

- At $30^{\circ} \mathrm{C}: 55 \%$ capacity

The differences in capacity may result from the fact that the batteries used in the first test (without radiators) were also applied in the second pack (with radiators) and in the second test. Discharge in a low temperature $\left(-20^{\circ} \mathrm{C}\right)$ may cause durable reduction of the capacity of particular batteries.

\section{Comparison of Battery Pack Test Results}

When analysing the battery's capacity depending on the discharge current value, the maximum energy can be obtained by discharging the battery with the current of $0.5 \mathrm{C}$ and $1 \mathrm{C}$ (the battery's capacity is similar in both cases). However, when $2 \mathrm{C}$ was selected, the value of obtained energy drops by about $10 \%$ (in comparison to the total/original capacity). By the application of higher discharge currents, lower battery capacity was obtained. However, in order to use the maximum capacity, we should apply the discharge currents below $1 \mathrm{C}$. Consequently, the minimum battery capacity should be associated with the maximum value of the discharge current required for a drone system. For an exemplary drone, the values can be: nominal value of $16 \mathrm{~A}$ and momentary value of $20 \div 30 \mathrm{~A}$. Therefore, the nominal capacity should amount to $30 \mathrm{Ah}$ not to exceed the discharge current of $1 \mathrm{C}$. Assuming the discharge current value of $1 \mathrm{C}$, the battery will be discharged in one hour. The momentary current will be used for several minutes at most.

A chemical reaction that generates electrons to supply the current of the battery, proceeds more slowly and lower current is produced when the battery is used at a low temperature. Low temperatures will cause decrease in battery capacity however can extend battery life during storage. Warming up the battery will restore its normal operation. Altitude also affects batteries negatively, especially above about $4,500 \mathrm{~m}$ in a non-pressurized cabin. If a battery is exposed to extreme weather conditions it may stop working, bulge, bubble, melt, cause damage, smoke, create sparks, create flames, expand, contract, and or even blow-up in very extreme cases. The combination of a rapid temperature change and low pressure can cause a potential hazard for the battery.

However, operating a battery at high temperatures temporarily improves performance by lowering the internal resistance and speeding up the chemical kinetics but also stresses the battery and reduces service life. Cold temperature increases the internal resistance and decreases the capacity.

The above conditions will be used for designing a proper battery cooling system. The conditions indicate that cooling is an indispensable element of the battery pack under consideration. 
The calculations of the quantities of the generated heat will be applied in the selection of proper heat control technology (radiators, thermally conductive tapes, or phase changing materials). Subsequent studies are recommended to be conducted in various environmental conditions, with the use of the environmental chamber, to test the influence of temperature and pressure on the battery operation. The environmental test results will help to select proper thermal insulation and, together with the present basic tests, they will constitute grounds for designing a proper heating/cooling systems for battery packs.

\section{ACKNOWLEDGEMENTS}

The authors are grateful to Professor Robert F. Savinell of the Case Western Reserve University, Cleveland for giving his valuable time to improve the quality of paper by providing scientific guidance.

\section{BIBLIOGRAPHY}

[1] Electric Vehicle Battery Test Procedures Manual, Revision 2, 1996.

[2] United States Council For Automotive Research LLC (USABC) Electric Vehicle Battery Test Procedures Manual.

[3] Bloom I., 2011, Battery Testing and Life Estimation in the US, US - China EV Initiative Workshop, Argonne National Laboratory.

[4] Cunningham B., , 2012, Overview and Progress of the Battery Testing, Design, and Analysis Activity, Energy Storage R\&D Hybrid and Electric Systems Team Vehicle Technologies Program, US Department of Energy, Energy Efficiency \& Renewable Energy.

[5] Winter M, Brodd RJ. 2004, "What are batteries, fuel cells, and supercapacitors?" Chemical Review, 104, pp. 4245-4269.

[6] Shoenung S.M., 2001, Characteristics and technologies for long- vs. short-term energy storage: a study by the DOE energy storage systems program, Technical report, SAND2001-0765, Sandia National Laboratories, United States Department of Energy.

[7] Krawczyk, M., 2012, "Reliability of the UAV", Transactions of the Institute of Aviation, 224, pp. 44-51.

[8] Mieloszyk, J. and Tarnowski, A., 2015, "Mass, Time and Cost Reduction in MAV Manufacturing”, Transactions of the Institute of Aviation, 1,(238), pp. 22-34.

[9] Sibilski K., Żyluk A., Kowalski W. and Wiśniowski W., 2015, "Simulation Studies of Micro Air Vehicle", Journal of KONES Powertrain and Transport, 4(22), pp. 243-252.

[10] Goraj, Z. and Szender, M., 2005, “Techniques and Critical Technologies applied for Small and Mini UAVS - State of the art and Development Perspectives", Transactions of the Institute of Aviation, 183, pp. 41-49.

[11] Hepperle M., 2012, Electric Flight - Potential and Limitations, German Aerospace Centre, Institute of Aerodynamics and Flow Technology, Germany.

[12] Krawczyk J.M., Mazur A.M., Sasin T. and Stokłosa A.W., "Fuel Cells as Alternative Power for Unmanned Aircraft Systems - Current Situation and Development Trends", Transactions of the Institute of Aviation, 4(237), pp. 49-62. 
[13] Krawczyk J. M., Mazur A. M., Sasin T., Stokłosa A. W., "Infrared Building Inspection with Unmanned Aerial Vehicles", Transactions of the Institute of Aviation, 3(240), pp. 32-48.

[14] Barcaro M., Bianchi N, and Magnussen F., 2009, "PM Motors for Hybrid Electric Vehicles", The Open Fuels \& Energy Science Journal, 2, pp. 135-141.

[15] Chen C., Man K.L., Ting T.O., Chi-Un Lei, Krilavičius T., Jeong T.T., Seon J.K., Sheng-Uei Guan Prudence and Wong W.H., 2012, "Design and Realization of a Smart Battery Management System", Proceedings of the International MultiConference of Engineers and Computer Scientists, II, IMECS 2012, Hong Kong.

[16] Bergveld H.J., 2001, "Battery Management Systems: Design by Modelling”, University Press Facilities, Eindhoven, Royal Philips Electronics N.V.

[17] Mills A. and Al-Hallaj S., 2005, "Simulation of passive thermal management system for lithium-ion battery packs", Elsevier, Journal of Power Sources 141, pp. 307-315.

[18] Technical Specification of a battery manufactured by the Israeli Amit Industries Ltd. company, type Amicell, model ABLP5274JOHG.

[19] Technical Specification of Airex T92 structural foam from: http://www.airexbaltekbanova.com/airex-t92-pet-foam.html].

\section{POMIAR I BADANIA PARAMETRÓW PAKIETU AKUMULATORA DO ZASILANIA BEZZALOGOWEGO SYSTEMU LATAJĄCEGO W RÓŻNYCH TEMPERATURACH}

\section{Streszczenie}

W artykule opisano wyniki badań oraz przedstawiono opis przeprowadzonych testów w celu sprawdzenia, w symulowanych warunkach środowiskowych, działania pakietu akumulatora, przeznaczonego do zasilania bezzałogowego systemu latającego. W szczególności dotyczy to określenia, kiedy akumulator ulega przegrzaniu lub przechłodzeniu i w jakim stopniu jest odporny na duże wahania temperatury. Do przeprowadzenia testów został wybrany akumulator litowo-polimerowy o wysokiej gęstości energii - Amicell, wyprodukowny przez Amit Industries Ltd. Wyniki testów przedstawiają charakterystyki akumulatorów testowanych w różnych temperaturach. Przeprowadzone próby umożliwią opracowanie i przetestowanie odpowiednich zabezpieczeń akumulatora przed warunkami środowiskowymi, pozwalając na jego ciągłe i poprawne działanie. Testy zostały przeprowadzone w akredytowanym Laboratorium Badań Środowiskowych, który jest częścią Zakładu Awioniki Instytutu Lotnictwa. Wszystkie wykonane testy bazowały na zatwierdzonych metodach badawczych oraz bieżącym nadzorze merytorycznym świadczonym przez pracowników Laboratorium Badań Środowiskowych.

Słowa kluczowe: akumulatory litowo-polimerowe, laboratorium badań środowiskowych, BSL, Bezzałogowe Systemy Latające. 